\title{
Factors Influencing the Sustainability of Quality Performance from the Viewpoint of Teaching Staff: An Applied Study at the University of Petra
}

\author{
Maram Fouad Abu Al-Nadi and Dina Mohamed Said Qarashay \\ University of Petra \\ Amman, Jordan
}

\begin{abstract}
This objective of this study is to identify the factors which influence the sustainability of the quality performance at Petra University from the faculty members' points of view. The participants were the teaching staff from the University of Petra. Out of 283 staff, 103 members took part in this study. A questionnaire consisting of 34 items was developed. The results showed that governance, educational programs, job satisfaction, and job performance were significant factors for the sustainability of quality performances at the University of Petra. The results also revealed that there is a meaningful relationship between sustainable factors and gender, while no significant differences could be attributed to academic rank or college type. Thus, these factors were recommended to be enhanced and developed based on quality standards.
\end{abstract}

Keywords: quality sustainability; job performance; faculty members; University of Petra

\section{Introduction}

The development of education in general and higher education, in particular, has become a necessity for writers, intellectuals and educators in the Arab world since the educational process did not achieve the desired objectives in keeping up with the scientific, technical, and informational developments. By establishing and developing specialized bodies or councils for academic accreditation and quality assurance, many Arab countries have strived for reforms in the higher education for the proper educational and academic standards that serve the community and the academic institution itself by (Taha, Taha \& Dalimi, 2015). However, a profound and radical changes in all aspects of society in connecting higher education with the needs and concerns of the community is required. A reconsideration of the function of the universities, providing the appropriate outputs to the labor market and the adoption of a knowledge-based economy is also required. Therefore, the development of personal skills and capabilities is a must (Mohammed, Jassim, Jbouri, Abdurahman \& Abdalrazzaq, 2015). 
The application of quality systems is essential in enhancing the current practices in the higher education institutions. It is also important to develop strategies and plans, take actions to fill the gaps, and optimize the possibilities for better performances (Al-Kasr, 2018). Quality of education reflects the ability of the educational institution to perform and prepare graduates capable of meeting the needs of the society and that of labor market (Mohammed, 2012). The University of Petra $(\mathrm{UoP})$ is a Jordanian university that plays a distinctive role in the preparation of cadres who are qualified for the achievement of comprehensive development of staff skills, knowledge enrichment and application of knowledge. The University of Petra is active in developing communication with its surrounding community, participating in regional and international scientific and cultural events in order to boost scientific research in various fields. Creating job opportunities, practicing its social responsibility, offering diverse educational programs, and updating its curriculum to align with the latest teaching methods and scientific research, are some of its other important objectives (University of Petra, 2019).

Currently, the world is witnessing a lot of competition in quality performance with focus on social opportunities and potential. A quality performance is an important process for management that necessitates planning and developing, and it need to be aligned with the needs and capabilities of the organisation. Quality objectives for higher education was summarised by Martin (2017).

\section{Quality objectives in higher education}

The goals of the quality assurance system in higher education institutions are as follows (Raqqad, 2014; Olimat, 2015; Al-Ameen, 2017): with the increase of higher education institutions, the government stressed that the quality of education to ensure that its outcomes meet the needs of the labor market must be controlled; accountability and transparency must be upheld in order to ensure that institutions of higher education are consistent with the general policy orientations of the state and current practices must be improved by conducting self-evaluation that helps decision-makers to develop strategies and plans towards better performance.

\section{Sustainability of quality performance in higher education institutions Governance}

The concept of university governance has recently emerged to reflect the real crisis of the institutions of higher education, where some universities develop its executive authority or make-decisions in isolation from students and staff members' interest. That reinforces the culture of the reluctance of participation, weakens the development of the university and the academic institution and scientific orientations. Due to the lack of transparency and management accountability mechanisms, the education process as a whole can be negatively affected. Accordingly, the government aims at bringing all parties to their responsibilities, which ultimately, it is hoped, will reflect in better performances from students, faculty members, administrative staff and other university staff (Halawah \& Taha, 2011). 


\section{Academic programs}

Academic programs are a set of mechanisms used to achieve knowledge, skills, and services provided by the university within a limited period. However, a collection of factors to achieving quality performance sustainability in the educational programs are: measurable and specific objectives of the academic programs, effectiveness of the curriculum, effectiveness of teaching and learning methods and the effectiveness of administrative mechanisms (Association of Arab Universities, 2015).

\section{Job satisfaction}

Many factors contribute to job satisfaction and these can be categorised into three groups (Ahmed, 2011): individual factors, organizational factors and environmental factors. Individual factors include the capacity of the personnel, their motivation, age, experience and scientific qualifications. Organizational factors are related to the organization type, work field, quality, and responsibilities of employees and the relationship among staff, colleagues, and supervisors. Environmental factors include the work environment, society's perception, employee appreciation of his/her own role and the his/her degree of integration in the workplace.

\section{Job performance}

This refers to the degree to which employee's tasks are to be fulfilled. Often, there is confusion and overlap between performance and effort, as the latter relates to the energy expended by the employee while performing a mission. In contrast, production is measured based on results, as emphasized by Abu Sharkh (2010) and Al-Froukh (2011). The organization can only compete if high performance is one of its most essential characteristics. This performance stems from the outcome of the individual performances in the organization as a whole.

\section{Problem statement}

The sustainability of quality in the performance of universities is one of the main pillars of a good education and one which is required to promote active learning that complies with the rapid technical, scientific, and cognitive evolution all over the globe. Hence, this study aims at revealing the factors which influence the sustainability of the quality performance of The University of Petra from the viewpoint of its teaching staff. The potential factors are shown in Figure 1.

\section{Questions of the study}

This study aims at answering the following questions:

Question 1: What are the factors influencing the sustainability of the quality performance of the University of Petra from the viewpoint of its faculty members? Question 2: Are there any significant differences at the $(\alpha \leq 0.05)$ level which influences the sustainability of quality performance of the University of Petra from the viewpoint of its faculty members owing to gender, academic rank, and college type? 


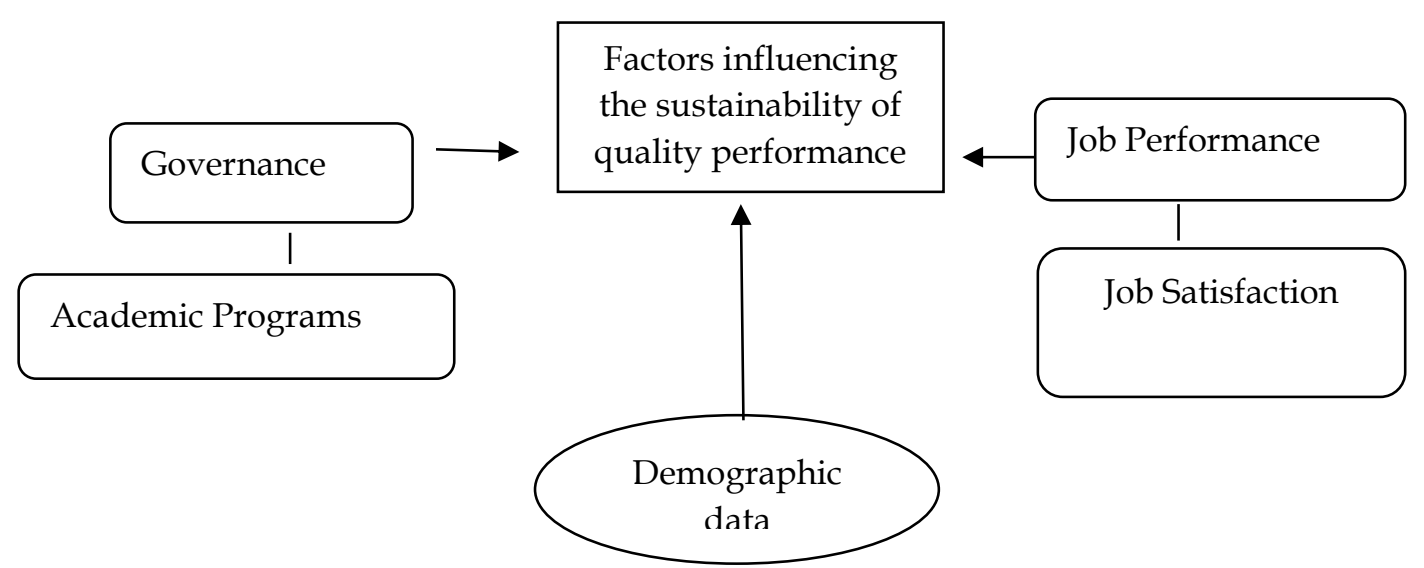

Figure 1. Factors influencing the sustainability of quality performance

\section{Importance of the study}

The significance of this study lies in the information and ideas associated with the quality of performance of Jordanian universities, which will contribute to the promoting of Jordanian higher education. The study results may benefit the Ministry of Higher Education with its accreditation programs, Presidents of Jordanian universities by improving the conditions of the institutional environment and researchers by providing a theoretical framework and a deeper insight into the factors which influence the sustainability of quality in Jordanian universities.

\section{Definitions}

Quality is a systematic process of class screening that leads to ensure excellent from educational institutions (or academic programs), meets regional and international standards so that the institutions can continuously improve its performance (Al-Khatib \& Al-Khatib, 2010). Sustainability of quality is recognized by the researcher as continuing quality, persistence, survival, and fulfilment through all the operations of the foundation. Job performance is the academic and administrative duties entrusted by the faculty members following the regulations and the instructions of the university (Sarairah, 2011).

\section{Limitations of the study}

The research was to the faculty members of the University of Petra in the 2017/2018 academic year. 


\section{Literature review}

Al-Nukari and Al-Tarawneh (2018) investigated the degree to which Jordanian universities achieve quality assurance standards from the deans of the faculties and academic department heads' point of view. 59 deans and 161 department heads took part in the study. They were chosen intentionally from three national and three private universities in Jordan. The findings showed that the degree to which Jordanian universities achieve quality assurance standards was high. According to the job title variable, there were significant differences at $(\alpha \leq 0.05)$ in the estimates of faculty deans and department heads of the degree to which Jordanian universities achieve quality assurance standards. Provision of material and moral support from deans and department heads can have a significant impact to which quality are met in Jordanian universities.

The study of Olkiewicz (2018) aimed at showing that improving quality through foresight could be a tool for shaping efficiency in the organization, which in turn might also be a way of strategic management and development of different aspects of the organization. The results showed that the application of foresight identifies organizational, administrative, and social changes that affect innovation (including the diversification of technological processes and automation), production dynamics, sales, and quality in the organization. The results also showed that "quality insight " can become a trend that includes the main strength to improve quality, competitiveness, productivity, and efficiency in the development of the organization.

Wei and Baocun (2018) studied the government-led university education assessment system in China which improved the quality of colleges and universities. They noted that China had conducted five rounds of evaluation since the 1990s and gradually developed a "five-in-one" evaluation system. The results showed that there were some problems in terms of diversity of evaluation subjects, dominance of government administration, lack of uniformity of the system, arbitrary application of evaluation, poor feedback channels for evaluation of results, and difficulty to achieve improvements. The study recommended that there should be exerted effort to increase the enthusiasm of colleges. Universities, however, should be promoted by strengthening their role of evaluation. In addition to enhancing evaluation laws, improving feedback channels, and allowing independent evaluation to be held substantially improves the quality of higher education.

A study by Tadesse, Manathunga and Gillies (2018) was aimed at identifying mechanisms to assess the quality of higher education but it was limited to compliance and accountability. It worked on studying the perceptions of a group of stakeholders on the quality of teaching and learning, evaluation, and review of experiences in higher education in Ethiopia. The results showed that current quality improvement efforts are fragmented and geared towards quality assurance rather than more general and permanent improvements. It also showed that most of the quality, evaluation concerns, and audit practices only led to more than mere preparation and execution of official reports in a very random manner. The study recommended an effective internal system, formative evaluation, and 
support for those working in the sector as a critical tool to implement quality improvements.

The main objective of Belash et al. (2015) was to evaluate quality assurance of educational programs according to the task (act, check, do, and plan), by monitoring the satisfaction of stakeholders with the results of education. One of the main findings of the study is that higher education institutions can adopt a methodology to monitor the satisfaction of students, graduates, and stakeholders as a mechanism to ensure the quality of academic programs.

A study by Badrakhan (2013) was aimed at assessing the extent of the application of quality standards, and quality assurance at the Amman National University in Jordan and to reveal the impact of the college and experience variables in the estimates of teaching staff members. The results showed that quality standards and quality assurance at the Amman National University was high. But it also showed a lack of impact on the experience and college variables in the opinions of faculty members and the adoption of inadequate incentive measures.

A study by Tarabulsieh (2011) was aimed at identifying the availability, the application of the areas of self-evaluation and quality standards in the Syrian higher education and scientific research institutions, based on views of a representative sample of faculty members and postgraduate students at Syrian government universities. The results showed that a low level of application of the self-evaluation areas and quality standards by faculty members and students.

An accreditation and quality control model for higher educational institutions in the Arab World was proposed by Al-Khatib \& Al-Khatib (2010). It was hoped that his model would contribute to improve the performances of universities, align their outputs with the requirements of the labor market and meets the needs of sustainable development plans. The results showed a very high degree of consensus among the members of the research sample (university presidents and their deputies, specialists in accreditation and quality control, members of the accreditation and quality control bodies, etc).

A study by Bouzian (2010) illustrated the advantages and disadvantages of applying total quality management in learning. The most important focus of the study was to support quality management, establish its own culture, organise continuous training for staff and delegation of authority. The study also stated that one of the obstacles is the lack of compatibility between the organizational cultures prevailing in educational institutions with quality management concerning the organizational cultural dimensions such as leadership structures, the need for continuous improvements and creativity. 


\section{Methodology}

A descriptive approach is the most appropriate method for this research.

\section{Population of the study}

The community of this research consists of all the faculty members at the University of Petra, which numbered 283, according to the official statistics issued by the Department of Higher Education for the year 2017/2018.

\section{Sample of the study}

The sample of the study consisted of 103 faculty members who were randomly selected from the population (Sekaran \& Bougie, 2016) but were then categorized by gender, academic rank and college type. Table 1 shows the distribution of the sample population according to these demographic variables.

Table 1: The distribution of the study sample

\begin{tabular}{|l|l|c|}
\hline Variables & Levels & No. \\
\hline \multirow{3}{*}{ Gender } & Male & 59 \\
\cline { 2 - 3 } & Female & 44 \\
\hline \multirow{4}{*}{ Academic Rank } & Assistant Professor & 64 \\
\cline { 2 - 3 } & Associate Professor & 24 \\
\cline { 2 - 3 } & Professor & 15 \\
\hline \multirow{2}{*}{ Type of college } & Humanities & 62 \\
\cline { 2 - 3 } & Applied Sciences & 41 \\
\hline Total & & 103 \\
\hline
\end{tabular}

\section{Study scale}

Based on the literature review, the researchers have set a questionnaire with 34 items to measure the factors influencing the sustainability of quality performance for the staff members, using the Likert scale (very high, high, medium, low, very low).

\section{Questionnaire authority}

The questionnaire has been presented to ten arbitrators in the same specialization to confirm the tool used in terms of construction integrity and clarity of language. The comments of the arbitrators were then taken into consideration to improve the questionnaire.

\section{Validity of scales}

The research instrument was reviewed in two different languages, English and Arabic, by academics. Thus, the researchers guarantee the validity of this tool.

\section{Reliability}

To assess the authenticity of the measurement scale and to evaluate the questionnaire internal consistency, a Cronbach Alpha value was calculated. The value for each area is provided in Table 2. 
Table 2: Internal consistency factors for each tool area

\begin{tabular}{|c|l|c|c|}
\hline No. & Area & Rank of paragraphs & Cronbach's Alpha \\
\hline 1 & Governance & 9 & .89 \\
\hline 2 & Academic programs & 14 & .90 \\
\hline 3 & Job satisfaction & 5 & .89 \\
\hline 4 & Job performance & 6 & .88 \\
\hline \multicolumn{2}{|c|}{ Total } & 34 & .96 \\
\hline
\end{tabular}

\section{Study variables}

Based on the research objectives and questions, the study variables were: gender (male and female), academic rank (assistant professor, associate professor, and professor), college type (humanities and applied sciences).

\section{Statistical tool}

The data collected from the questionnaires were analyzed using SPSS v22, along with the following: the number of times a repeating event occurs per unit of time (frequency), measures of central tendency, extraction of arithmetic mean and standard deviation, T-tests to determine the significance and differences between the independent variables and Cronbach Alpha to verify the stability of the coefficient for internal consistency. The 5-grade Likert scale for respondents' scores was used as the following: very weak (1.00 to 1.80), weak (1.81-2.60), medium (2.61-3.40), high (3.41-4.20) and very high (4.21-5.00).

\section{Results}

Question 1: What are the factors influencing the sustainability of the quality performance of the University of Petra according to staff opinion?

To answer this question arithmetic means and standard deviations for factors influencing the sustainability of quality performance of the University of Petra, were calculated. The results reveal that governance was ranked first with an average of 4.54 and a standard deviation of 0.53 , followed by academic programs with an average of 4.41 and a standard deviation of 0.51 . In contrast, job satisfaction ranked third with an average of 4.39 and a standard deviation of 0.72 . However, the fourth place was occupied by job performance with an average of 4.30 and a standard deviation of 0.73 , as shown in Table 3.

Table 3. Arithmetic means and standard deviations of the factors influencing the sustainability of quality performance of the University of Petra

\begin{tabular}{|l|l|c|c|l|}
\hline Rank & Area & Mean & Standard deviation & Degree \\
\hline 1 & Governance & 4.54 & .53 & Very high \\
\hline 2 & Academic Programs & 4.41 & .51 & Very high \\
\hline 3 & Job satisfaction & 4.39 & .72 & Very high \\
\hline 4 & Job Performance & 4.30 & .73 & Very high \\
\hline \multicolumn{2}{|l|}{ Scale as a whole } & 4.42 & .52 & Very high \\
\hline
\end{tabular}




\section{Governance}

Arithmetic means and standard deviations were used to determine the impact on governance on the quality performance sustainability at the University of Petra. The results demonstrate that item 1, which states that "work on issuing regulations, instructions and policies", ranked first with an average of 4.74 and a standard deviation of 0.52. Item 5 which states that "the existence of the governance councils and defining their tasks and responsibilities" ranked second with an average of 4.70 and a standard deviation of 0.58 . Item 9 which states that "the existence of procedures for awarding, penalties and follow-up of grievances" ranked last with an average of 4.35 and a standard deviation of 0.83 . However, the mean for this domain as a whole was 4.54 and the standard deviation was 0.53 , which equals a "very high" rating, as shown in Table 4.

Table 4: Mean and standard deviations of the study sample estimates of the impact of governance on quality sustainability in the performance of the University of Petra

\begin{tabular}{|c|c|c|c|c|c|}
\hline No. & Paragraphs & Mean & $\begin{array}{l}\text { Standard } \\
\text { deviation }\end{array}$ & Rank & Degree \\
\hline 1 & $\begin{array}{l}\text { Working on the promulgation } \\
\text { of regulations, instructions, and } \\
\text { policies. }\end{array}$ & 4.74 & .52 & 1 & Very high \\
\hline 5 & $\begin{array}{l}\text { The existence of the governing } \\
\text { councils and the definition of } \\
\text { their tasks and responsibilities. }\end{array}$ & 4.70 & .58 & 2 & Very high \\
\hline 2 & $\begin{array}{l}\text { Work on evaluation, review, } \\
\text { and development. }\end{array}$ & 4.60 & .65 & 3 & Very high \\
\hline 3 & $\begin{array}{l}\text { Working on documentation and } \\
\text { publishing. }\end{array}$ & 4.59 & .66 & 4 & Very high \\
\hline 7 & $\begin{array}{l}\text { Application of transparency in } \\
\text { the implementation of all the } \\
\text { work of the enterprise. }\end{array}$ & 4.53 & .78 & 5 & Very high \\
\hline 6 & $\begin{array}{l}\text { Existence of performance } \\
\text { appraisal and accountability } \\
\text { procedures. }\end{array}$ & 4.53 & .75 & 5 & Very high \\
\hline 4 & $\begin{array}{l}\text { Adoption of organizational } \\
\text { structures and mechanisms for } \\
\text { their construction and review. }\end{array}$ & 4.42 & .86 & 6 & Very high \\
\hline 8 & $\begin{array}{l}\text { Existence of justice and equal } \\
\text { opportunity procedures. }\end{array}$ & 4.40 & .87 & 7 & Very high \\
\hline 9 & $\begin{array}{l}\text { Existence of procedures for } \\
\text { granting incentives, sentencing, } \\
\text { and follow-up of grievances. }\end{array}$ & 4.35 & .83 & 8 & Very high \\
\hline \multicolumn{2}{|c|}{ The area as a whole } & 4.54 & .53 & & Very high \\
\hline
\end{tabular}


The researchers attribute this finding to the fact that the University of Petra depends on governance for the sustainability of is quality. It takes organizational and administrative structures that correspond with its mission and objectives to develop operational plans, regulations, instructions, and policies, as well as defining the tasks and responsibilities and actions to assess performance and accountability. All these are within the framework of equal opportunities and justice for all employees of the university. Nevertheless, specific procedures for awarding incentives or penalizing through transparency exist.

This result is in contrast with the findings of Tadesse, Manathunga and Gillies (2018), who showed that quality improvement efforts are separated, and most of the quality and evaluation concerns and administration practices lead only to the preparation and execution of randomly placed official reports. However, the results are in agreement with Bouzian (2010), who showed that the most critical focus of research is to support quality management, establish a culture of continuous training in individuals and to delegate authority. Our results are also in agreement with Al-Nukari and Al-Tarawneh (2018).

\section{Academic programs}

Arithmetic means and standard deviations were calculated to determine the impact of educational programs on the sustainability of quality at the University of Petra. The results show that item 15, which states that "clearness of the study plans for the programs offered", has ranked first with an average of 4.72 and a standard deviation of 0.49 . Item 10 , which states that "foundation, development, and cessation of academic programs", ranked second with an average of 4.55 and a standard deviation of 0.70 . Item 1), which states that "an interactive relationship between faculty members and staff of database and library" ranked last with an average of 4.17 and a standard deviation of 0.94 . However, the mean for this domain as a whole was 4.41 and the standard deviation was 0.51 , which equals a "high" rating, as shown in the Table 5.

Table 5: Mean and standard deviations of the study sample on the impact of academic programs on the durability of quality in the performance of University of Petra

\begin{tabular}{|c|l|c|c|c|c|}
\hline No. & Paragraphs & Mean & $\begin{array}{c}\text { Standard } \\
\text { deviation }\end{array}$ & Rank & Degree \\
\hline 15 & $\begin{array}{l}\text { Clarity and complementarity of } \\
\text { study plans for the programs. }\end{array}$ & 4.72 & .49 & 1 & $\begin{array}{c}\text { Very } \\
\text { high }\end{array}$ \\
\hline 10 & $\begin{array}{l}\text { Establishment, development, and } \\
\text { discontinuation of academic } \\
\text { programs. }\end{array}$ & 4.55 & .70 & 2 & $\begin{array}{c}\text { Very } \\
\text { high }\end{array}$ \\
\hline 11 & $\begin{array}{l}\text { The existence of policies and } \\
\text { procedures for student transition } \\
\text { and equivalency of courses. }\end{array}$ & 4.48 & .64 & 3 & $\begin{array}{c}\text { Very } \\
\text { high }\end{array}$ \\
\hline 18 & $\begin{array}{l}\text { An adequate number of teachers } \\
\text { with appropriate qualifications and } \\
\text { disciplines for programs and levels. }\end{array}$ & 4.48 & .77 & 3 & $\begin{array}{c}\text { Very } \\
\text { high }\end{array}$ \\
\hline
\end{tabular}




\begin{tabular}{|c|l|c|c|c|c|}
\hline No. & Paragraphs & Mean & $\begin{array}{c}\text { Standard } \\
\text { deviation }\end{array}$ & Rank & Degree \\
\hline 16 & $\begin{array}{l}\text { The harmony between the } \\
\text { applications presented with the } \\
\text { university vision, mission, and goals. }\end{array}$ & 4.47 & .65 & 4 & $\begin{array}{c}\text { Very } \\
\text { high }\end{array}$ \\
\hline 21 & $\begin{array}{l}\text { The existence of policies and } \\
\text { procedures for evaluating student } \\
\text { performance. }\end{array}$ & 4.44 & .79 & 5 & $\begin{array}{c}\text { Very } \\
\text { high }\end{array}$ \\
\hline 19 & $\begin{array}{l}\text { Providing the necessary educational } \\
\text { resources for academic programs. }\end{array}$ & 4.42 & .79 & 6 & $\begin{array}{c}\text { Very } \\
\text { high }\end{array}$ \\
\hline 22 & $\begin{array}{l}\text { Policy and procedures for the } \\
\text { performance appraisal of faculty } \\
\text { members are available. }\end{array}$ & 4.40 & .73 & 7 & $\begin{array}{c}\text { Very } \\
\text { high }\end{array}$ \\
\hline 14 & $\begin{array}{l}\text { Working on the publication of } \\
\text { expected learning outcomes for all } \\
\text { academic programs offered. }\end{array}$ & 4.40 & .83 & 7 & $\begin{array}{c}\text { Very } \\
\text { high }\end{array}$ \\
\hline 20 & $\begin{array}{l}\text { Commitment to the time allotted for } \\
\text { the plans presented. }\end{array}$ & 4.38 & .76 & 8 & $\begin{array}{l}\text { Very } \\
\text { high }\end{array}$ \\
\hline 12 & $\begin{array}{l}\text { Continuous improvement of } \\
\text { teaching and learning processes. }\end{array}$ & 4.31 & .85 & 9 & $\begin{array}{l}\text { Very } \\
\text { high }\end{array}$ \\
\hline The area as a whole & $\begin{array}{l}\text { The existence of academic guidance } \\
\text { programs for students. }\end{array}$ & 4.31 & .83 & $\begin{array}{l}\text { Very } \\
\text { high }\end{array}$ \\
\hline $\begin{array}{l}\text { An interactive relationship between } \\
\text { databases. }\end{array}$ & 4.17 & .94 & 11 & High \\
\hline
\end{tabular}

The researchers attribute this 'very high' result for the quality of academic programs at Petra University due to the clarity of vision in these programs, the knowledge of resource persons, the presence of learning outcomes, measurable skills, and that the objectives of these programs are international known. The continuous educational development for faculty members through participation in research, training in the latest scientific education and keeping up with the recent advancements in the different fields of specialization has also helped the University of Petra achieved this 'very high' result. It should also be noted that there is constant communication between faculty members and technical \& administrative staff. Moreover, there is a fluid communication between faculty members and students, with an integrated information system being to evaluate the work of faculty members so that they can improve their performances. 
This result agrees with Belash et al. (2015), who showed that higher education institutions can adopt a methodology to measure the satisfaction of undergraduates, graduates and other stakeholders in order to ensure the quality of academic programs. The added value approach confirms the validity of the graduate satisfaction for the education they are receiving.

\section{Job satisfaction}

Arithmetic means and standard deviations were calculated to determine the impact of job satisfaction on the sustainability of quality at the University of Petra. The results show that items 27 and 24, which respectively states that "the participation of faculty members in the process evaluation of educational outcomes" and "the staff member's sense of job security at the university", have together occupied the first place with a common average of 4.46 but with standard deviations of 0.85 and 0.88 , respectively. Item 26 , which states that "the participation of faculty member in decision-making concerning education and learning policies", has ranked in the second place with an average of 4.38 and a standard deviation of 0.81 . Item 25, which states that "the faculty member is supported when exposed to an administrative problem", ranked last with an average of 4.31 and a standard deviation of 0.88 . However, the mean for this area as a whole was 4.41 and the standard deviation was 0.51, which equals a "very high" assessment rating, as shown in Table 6.

Table 6: Mean and standard deviation for the sample estimates of the impact of functional satisfaction on quality sustainability at the University of Petra

\begin{tabular}{|c|l|c|c|c|c|}
\hline No. & Paragraph & Mean & $\begin{array}{c}\text { Standard } \\
\text { deviation }\end{array}$ & Rank & Degree \\
\hline 27 & $\begin{array}{l}\text { Involvement of faculty members in } \\
\text { the process evaluation of educational } \\
\text { outcomes. }\end{array}$ & 4.46 & .85 & 1 & $\begin{array}{l}\text { Very } \\
\text { high }\end{array}$ \\
\hline 24 & $\begin{array}{l}\text { The staff member's sense of job } \\
\text { security at the university. }\end{array}$ & 4.46 & .88 & 1 & $\begin{array}{l}\text { Very } \\
\text { high }\end{array}$ \\
\hline 26 & $\begin{array}{l}\text { The participation of a member of the } \\
\text { teaching staff to make decisions to } \\
\text { develop education and learning } \\
\text { policies. }\end{array}$ & 4.38 & .81 & 2 & $\begin{array}{l}\text { Very } \\
\text { high }\end{array}$ \\
\hline $\begin{array}{l}\text { The satisfaction of the teaching staff } \\
\text { about the services provided } \\
\text { (appointment, training, scholarship, } \\
\text { attendance at conferences, etc) }\end{array}$ & 4.35 & .92 & 3 & $\begin{array}{c}\text { Very } \\
\text { high }\end{array}$ \\
\hline 25 & $\begin{array}{l}\text { The faculty member received support } \\
\text { when exposed to an administrative } \\
\text { problem. }\end{array}$ & 4.31 & .88 & 4 & $\begin{array}{l}\text { Very } \\
\text { high }\end{array}$ \\
\hline The area as a whole & 4.39 & .72 & & $\begin{array}{l}\text { Very } \\
\text { high }\end{array}$ \\
\hline
\end{tabular}


The views of the teaching staff on the job satisfaction were in the 'very high' category, which confirms that the working environment and the organizational climate at the university are very comfortable, and that their job provides them with an appropriate social status. The researchers also attribute this result to the fact that the improvement of the work environment had a vital role in increasing the employee's loyalty with their organizations. When faculty members work in an appropriate and comfortable work environment, they will provide the organization with all their energies they can. The positive work environment, such as the freedom in making decisions, participation in the evaluation processes, clarity of responsibilities, appropriate rules and regulations, and organizational support contribute to raising the level of efficiency of the scholars and increasing job satisfaction, which automatically increase productivity. The University of Petra also encourages opportunities for professional development, and self-development, which can guarantee job security. However, our results are not in agreement with Bouzian (2010), as his results showed that one of the most critical constraints towards quality practices is the inadequacy of the organizational culture at the educational institutions. And this is to the following obstructions: the centralization of decision-making, staff weakness and inability in the field of quality management, inadequate quality of the educational service offered to students to meet their expectations and needs, the lack of association between the university and the relevant sectors of the labor market, and the resistance to change by specific employees or whole departments.

\section{Job performance}

Arithmetic means and standard deviations were calculated to determine the impact of job performance on the sustainability of quality at the University of Petra. The results showed that item 29, which states that "the commitment of faculty members to the areas of continuous improvement", ranked first with an average of 4.50 and a standard deviation of 0.74 . Item 30 , which states that "the presence of open channels of communication between different administrative levels", ranked second with an average of 4.36 and a standard deviation of 0.84 . Item 33 , which states that "the university adopts reference of comparisons to measure job performance", ranked last with an average of 4.18 and a standard deviation of 1.06. Thus, the mean on this domain as a whole was 4.30 and the standard deviation was 0.73 , which equals a "very high" rating, as shown in Table 7.

The researchers attribute this 'very high' result for the job performance variable to the constant improvements that are done in this area at the University of Petra. The results have also shown that the more the university improvements increase, the more the job performance increase. Hence, universities should work on an ongoing growth in their staff. Also, the application of quality management and its role in improving the performance of employees will help in the employment of the concept of quality assurance system. These results are in agreement with the study done by Badrakhan (2013), in which the application of quality standards and quality assurance at Amman National University came first. Badrakhan (2013) study focused on the need to adopt adequate incentive systems for workers in order to increase their productivity. 
Table 7: Mean and standard deviations for the study sample estimates of the impact of job performance on the sustainability of quality at the University of Petra

\begin{tabular}{|c|l|c|c|c|c|}
\hline No. & Paragraph & Mean & $\begin{array}{c}\text { Standard } \\
\text { deviation }\end{array}$ & Rank & Degree \\
\hline 29 & $\begin{array}{l}\text { The commitment of faculty members } \\
\text { to the areas of continuous } \\
\text { improvement. }\end{array}$ & 4.50 & .74 & 1 & $\begin{array}{l}\text { Very } \\
\text { high }\end{array}$ \\
\hline 30 & $\begin{array}{l}\text { The presence of open channels of } \\
\text { communication between different } \\
\text { administrative levels. }\end{array}$ & 4.36 & .84 & 2 & $\begin{array}{l}\text { Very } \\
\text { high }\end{array}$ \\
\hline 32 & $\begin{array}{l}\text { The university adopts standards for } \\
\text { the measurement of job performance. }\end{array}$ & 4.32 & .94 & 3 & $\begin{array}{l}\text { Very } \\
\text { high }\end{array}$ \\
\hline 31 & $\begin{array}{l}\text { Faculty members benefit from } \\
\text { feedback in continuous improvement } \\
\text { processes. }\end{array}$ & 4.21 & .98 & 4 & $\begin{array}{c}\text { Very } \\
\text { high }\end{array}$ \\
\hline $\begin{array}{l}\text { Participation of faculty in follow-up } \\
\text { committees for the development of } \\
\text { quality assurance management. }\end{array}$ & 4.19 & .93 & 5 & High \\
\hline 33 & $\begin{array}{l}\text { Observance by the University of } \\
\text { benchmarking for the measurement } \\
\text { of functional performance. }\end{array}$ & 4.18 & 1.06 & 6 & High \\
\hline The area as a whole & 4.30 & .73 & $\begin{array}{l}\text { Very } \\
\text { high }\end{array}$ \\
\hline
\end{tabular}

Question 2: Are there significant differences at the level of significance ( $\alpha \leq$ 0.05 ) in the factors influencing the sustainability of quality performance of the University of Petra according to faculty staff due to the variables (gender, academic rank, and college type)?

A multivariate analysis of variance was used to measure the demographic variables of gender, academic rank, and college type. Table 8 shows the relevant statistics for each of the demographic variable.

There were no significant differences at level $(\alpha \leq 0.05)$ between the study groups in the factors influencing the sustainability of quality performance of the University of Petra attributed to the academic rank variable and all areas of the tool. There were also significant differences at level $(a \leq 0.05)$ between study groups in the factors influencing the sustainability of quality in the performance of the University of Petra attributed to the variable of the college type and all areas of the tool.

However, the study revealed that there were significant differences at the level (a $\leq 0.05$ ) between the study groups averages in the factors influencing the sustainability of quality performance of the University of Petra and all areas of the tool in favor of females. The detailed results are provided in Table 9. 
Table 8: Results of multivariate analysis of variance for sample estimates of factors influencing the sustainability of quality in the performance the University of Petra

\begin{tabular}{|c|c|c|c|c|c|c|}
\hline Variables & Areas & $\begin{array}{c}\text { Sum of } \\
\text { squares }\end{array}$ & Freedom Degrees & $\begin{array}{l}\text { Mean of } \\
\text { squares }\end{array}$ & F Ratio & $\begin{array}{l}\text { Sig. } \\
\text { level }\end{array}$ \\
\hline \multirow{4}{*}{$\begin{array}{l}\text { Gender } \\
\text { Hoteling } \\
\text { value }=.805\end{array}$} & Governance & 1.832 & 1 & 1.832 & 6.955 & $.010^{*}$ \\
\hline & Academic Programs & 1.206 & 1 & 1.206 & 4.682 & $.033^{*}$ \\
\hline & Job satisfaction & 2.522 & 1 & 2.522 & 5.174 & $.025^{*}$ \\
\hline & Job Performance & 3.716 & 1 & 3.716 & 7.484 & $.007^{*}$ \\
\hline \multirow{4}{*}{$\begin{array}{l}\text { Academic } \\
\text { rank } \\
\text { Wilks value } \\
=.909\end{array}$} & Governance & .741 & 2 & .370 & 1.406 & .250 \\
\hline & Academic Programs & .070 & 2 & .035 & .136 & .873 \\
\hline & Job satisfaction & 2.991 & 2 & 1.495 & 3.068 & .051 \\
\hline & Job Performance & 1.229 & 2 & .614 & 1.237 & .295 \\
\hline \multirow{4}{*}{$\begin{array}{l}\text { College type } \\
\text { Hoteling } \\
\text { value }=.037\end{array}$} & Governance & .256 & 1 & .256 & .972 & .327 \\
\hline & Academic Programs & .188 & 1 & .188 & .728 & .396 \\
\hline & Job satisfaction & .002 & 1 & .002 & .004 & .950 \\
\hline & Job Performance & .715 & 1 & .715 & 1.440 & .233 \\
\hline \multirow{4}{*}{ Error } & Governance & 25.814 & 98 & .263 & & \\
\hline & Academic Programs & 25.249 & 98 & .258 & & \\
\hline & Job satisfaction & 47.759 & 98 & .487 & & \\
\hline & Job Performance & 48.658 & 98 & .497 & & \\
\hline
\end{tabular}

* Statistical significance level $(\alpha \leq 0.05)$

Table 9: Mean and standard deviation of sample estimates in all areas depending on the differences in gender

\begin{tabular}{|l|l|c|c|c|}
\hline Area & Gender & No. & Mean & Standard deviation \\
\hline \multirow{3}{*}{ Governance } & Male & 59 & 4.44 & .59 \\
\cline { 2 - 5 } & Female & 44 & 4.68 & .41 \\
\hline \multirow{3}{*}{ Academic Programs } & Male & 59 & 4.32 & .51 \\
\cline { 2 - 5 } & Female & 44 & 4.53 & .50 \\
\hline \multirow{2}{*}{ Job satisfaction } & Male & 59 & 4.28 & .77 \\
\cline { 2 - 5 } & Female & 44 & 4.53 & .62 \\
\hline \multirow{2}{*}{ Job Performance } & Male & 59 & 4.15 & .80 \\
\cline { 2 - 5 } & Female & 44 & 4.49 & .58 \\
\hline
\end{tabular}

The researchers attributed the existence of the statistically significant difference assigned to the gender variable in favor of females due to the fact that females are more eager to maintain quality standards, and more interested in the continuous development, quality sustainability and the upgrading of their job performances. The researchers also attributed the absence of significant differences in the level 
of academic rank and the type of college to the administrative burdens that are too often assigned to faculty members despite the fact that they are too often overloaded with teaching and research activities. Some tasks are allocated according to their academic rank (Professor, Associate Professor, Assistant Professor) while many other tasks have to be completed by all of them, irrespective of their rank. These results are in agreement with those of Badrakhan (2013), who also showed the lack of impact of college type on quality standards and quality assurance at the Amman National University from. Furthermore, the function of faculty members is very specific regardless of the type of college they work in. This explains the lack of impact of 'college type' as a factor in the maintenance of quality in the above universities.

\section{Conclusions and Recommendations}

The response of the sample members to the factors influencing the quality sustainability of the performance of Petra University has been "very high". And that the area of governance was ranked first for the other areas mentioned in the study. And that there are statistically significant differences for the study variables, namely the type of college and the sex in favor of females. Further to these findings, this paper presents a set of recommendations that shall contribute to the identification of factors influencing the sustainability of quality performance of the University of Petra. Since the responses of the faculty members to the factors influencing the sustainability of quality performance at the University of Petra were "very high", we recommend the following: researchers shall take care of these factors and work on developing them regularly based on the quality standards and their usage at universities along with other factors, the development of a rewarding system for excellence in teaching \& research and/or distinctive performances in administrative duties or other university-related matters, the adoption of a fair and measurable evaluation system which can integrate the various processes of the university and the adoption of transparent and accountable standards in all administrative and technical duties at the university.

\section{References}

Abu Sharkh, N. H. (2010). Assessment of the Impact of incentives on the Work performance level in the Palestinian Telecommunication Company: Employee perspective of the Egyptians (Master's thesis). Al-Azhar University: Gaza.

Ahmed, T. I. (2011). Job Satisfaction According to Some Personal Variables for Faculty and Administrative Staff in the Departments and Colleges of Physical Education: The University of Mosul, al-Rafidain. Journal of Mathematical Sciences, 17(57), 63-82.

Al-Ameen, F. K. (2017). Application of Quality Standards in Governance and Management in Higher Education Institutions in Sudan Experience Deanship of Quality and Academic Development at the University of Niles. Graduate Journal of the Nile University, 7(28), 182-217.

Al-Froukh, F. A. R. (2011). Organizational Learning and its Impact on Improving Job Performance, Dar Jalees Alzaman Publishing and Distribution, Amman, Jordan.

Al-Kasr, S. A. (2018). The Role of Inclusive Quality Criteria in Applying the Administrative Governance at Universities (Applicative Study on the Private Universities in Riyadh). Journal of the Faculty of Basic Education for educational and Humanities Sciences, 39, 417-430. 
Al-Khatib, A., \& Al-Khatib, R. (2010). Accreditation and Quality Control in Arab Universities (first edition). Jordan, Irbid: Modern book Science.

Al-Nukari, E., M., \& Al-Tarawneh, E, Y. (2018). The Degree to which Jordanian Universities Achieve Quality Assurance Standards from the Dean of the Faculties and Academic Department Heads' Point of View. Dirasat Journal, Educational Science, 45(3).

Association of Arab Universities (2015). Guide for Quality Assurance of Academic Programmes at Arab Universities Faculties. Union of Arab Universities Secretariat general, Amman, Jordan. Retrieved from http://www.aaru.edu.jo/Documents/Quality\%20Assurance/DistanceLearning Guide_Final_01.pdf

Badrakhan, S. (2013). The Extent of Application of Quality Standards and Quality Assurance by Al-Ahliyya Amman University from Faculty Members, BALQA. Journal for Research and Studies, 16(1), 59-87.

Belash, O., Popov, M., Ryzhov, N., Ryaskov, Y., Shaposhnikov, S., \& Shestopalov, M. (2015). Research on University Education Quality Assurance: Methodology and Results of Stakeholders' Satisfaction Monitoring. Social and Behavioral Sciences, 214, 344-358.

Bouzian, R. (2010). The Reality of the Implementation of Comprehensive Quality Management in the Algerian Higher Education Institutions, the First International Meeting of Quality Assurance Stakes in Higher Education. The Forum of Universities of Eastern Algeria. Algeria.

Halawah, J., \& Taha, N. (2011). Reality of Governorship at the University of Jerusalem". University of Jerusalem, Institute of Sustainable Development, House of Developmental Science, Jerusalem, Palestine.

Martin, M. S. (2017). Assurance Qualité Externe Dans L'enseignement Supérieure: Les Options. UNESCO, Paris. Retrieved from https://unesdoc.unesco.org/ark:/48223/pf0000152045_fre

Mohammed, D. M. (2012). The Quality of Continuing Higher Education Institutions and the Challenges of Knowledge. $2^{\text {nd }}$ Arab International Conference for Higher Education Quality Assurance, Cairo University, Egypt.

Mohammed, S. (2015). A Proposal Vision for Quality Assurance of the Egyptian Higher Education in the Light of Strategic Management Approach. The Arab Journal for the Quality Assurance of University Education, 8(19), 85-133.

Mohammed, T., Jassim, F., Jbouri, B., Abdurahman, M., \& Abdalrazzaq, Z. (2015,1 $1^{\text {st }}$ of march). An Analytical Study of the Role of the Higher Leadership in the University of Technology in Applying the Standards and Requirements of Total Quality Management in Higher Education. 5th Arab Higher Education Quality Assurance Conference, Sharjah University, United Arab Emirates. Retrieved on 20/11/2018, from: http://zu.edu.jo/EN/NewsForm/NewsDetails.aspx?id=1413

Olimat, S. (2015). Quality and academic accreditation at Jordanian universities. Paper presented at the Seventh Annual conference: The Impact of quality and accreditation in education, Casablanca: Morocco. Retrieved from http://events.aroqa.org/uploads/newsImage/file/proceedings2015_(9).pdf

Olkiewicz, M. (2018). Quality Improvement through Foresight Methodology as a Direction to Increase the Effectiveness of an Organization. Contemporary Economics, 12(1), 69-80.

Raqqad, S. (2014). Application of the Quality Assurance System in Algerian Higher Education Institution (Thesis submitted for a PhD in Economic Sciences) Sateef University, Algeria. Retrieved from http://www.univsetif.dz/Tdoctorat/2015/SEG/regad\%20saliha.pdf 
Sarairah, K. (2011). The job performance of the faculty members in the official Jordanian universities from the point of view of the department heads. Damascus University Journal, 27(1), 601-652.

Sekaran, U., \& Bougie, R. (2016). Research Methods for Business: A Skill Building Approach (7th Edition). Retrieved from https://www.academia.edu/36294585/ResearchMethods-For-Business-A-Skill-Building-Approach-7th_edition.pdf

Tadesse, T., Manathunga, C., \& Gillies, R. (2018). Making sense of quality teaching and learning in higher education in Ethiopia: Unfolding existing realities for future promises. Journal of University Teaching \& Learning Practice, 15(1), 1-20.

Taha, H., Taha, A., \& Dalimi, A. (2015, $1^{\text {st }}$ of March). Comprehensive quality and scientific research in Arab higher education institutions. Paper presented in the 5th International Arab Conference on Quality Assurance in Higher Education, Sharjah University, United Arab Emirates.

Tarabulsieh, S. M. (2011). Quality Management of Educational and Research Services in Higher Education Institutions ( $1^{\text {st }}$ edition). Arab Society Publishing and distribution Office.

University of Petra (2019, December 16). About University of Petra. (Website) Retrieved from https://www.uop.edu.jo/En/Pages/default.aspx

Wei, Z., \& Baocun, L. (2018). The Undergraduate Teaching Evaluation System in China: Progress, Problems, and Suggestions. Chinese Education \& Society, 51, 248-259. 